\title{
Climate Change-Induced Impact on Water Resource of Ladakh Cold Arid Region
}

\author{
Jigmet Yangchan ${ }^{1}$, M.S. Raghuvanshi ${ }^{2}$, Anil Kumar ${ }^{1 *}$ and C.K. Arya ${ }^{3}$ \\ ${ }^{1}$ High Mountain Arid Agricultural Institute, Sher-E-Kashmir University of Agriculture Science \\ and Technology, Leh-Ladakh-194101 (J\&K), India \\ ${ }^{2}$ ICAR-National Bureau of Soil Survey and Land Use Planning, Nagpur-440033 \\ (Maharashtra), India \\ ${ }^{3}$ College of Horticulture \& Forestry, (Agriculture University, Kota)-Jhalawar-326023 \\ Rajasthan, India \\ *Corresponding author
}

\section{A B S T R A C T}

\begin{tabular}{|l|}
\hline Ke y w o r d s \\
Water resources, \\
Ladakh region, \\
spring, Indus, Zing, \\
glacier
\end{tabular}

\section{Introduction}

Ladakh region in Himalayan range is characterized as excessive arid and severe moisture deficit region throughout the year. With scarce water resources, such regions show high sensitivity and vulnerability to the
This paper is about the impact of climate change on water resources, mainly focusing upon the consequences of climate change on Ladakh people based on both qualitative and quantitative approaches. Inadequacy of water resources, irregular rainfall pattern and coping up under such scared water consequences are the major problems in the study area. The main sources of water are glaciers, hand pump, stream and springs. Survey revealed that almost $50 \%$ people responded on the impact of climate change; $30 \%$ responded due to increase in population and consequently increased demand of water and remaining $20 \%$ responded for no impact. Majority of them conveyed the Chem-Sak is water scared. As $60 \%$ Chem-sak people mentioned that quality and quantity of water are differed in last 25 years. People has observed the climatic hazards like cloudburst and flood, and facing frequently. Finally, it was observed that the people started the adjusting with the changing climate and need with available water resources over the last 25 years, confirming the declining of water resources and their potential in fulfilling the demand of the Ladakhi people as the risks are changing as a result of rapid climatic and socio-economic changes due to groundwater vulnerability. On the other hand, climate change in Ladakh has triggered the immediate melt water runoff and water supply is decreasing drastically. 
the region and its contribution has increased manifold in the wake of recent spurt in bore well installations, especially, in Leh-Town (Dolma et al., 2015). Ladakh which is currently under arid and semiarid region is likely to experience water stress conditions, lack of soil moisture and water holding capacity, and desert expansion. In general, the linear decreasing pattern of precipitation.In these last few years, it was visible in Ladakh the impact of global climate change has been increasing very rapidly. Rainfall pattern have been changing, small glaciers and permanent snow field are melting and temperature rise has been affecting water runoff in the rivers. In winter the snow pattern shift to Feb and March by in less quantity. It clearly indicates erratic behavior of precipitation in Ladakh in last few years. Khardung Pass which used to be completely covered by a layer of thick snow about 4 meters (in July) until 1995 is witnessing new predicament. The Pass has no snow or less snow in year 2017.

Climate Change (CC) is a significant and lasting change in the statistical distribution of weather patterns over periods ranging from decades to millions of years (Tiwari et al, 2015). So climate change is caused by different reasons. It may be a change in average weather conditions or in the distribution of weather around the average conditions (i.e., more or fewer extreme weather events). Climate change is closely related in all the sectors (Kankia, 2012) highlights that, "Climate change is caused by factors that include oceanic processes (such as oceanic circulation), variations in solar radiation received by Earth, plate tectonics and volcanic eruptions, and human-induced alterations of the natural world; these latter effects are currently causing global warming, and "climate change" is often used to describe human-specific impacts". Watershed Planning, 2008 states that, Even greater changes are expected in the future, including a continued rise in temperatures, shifts in rainfall patterns, and increases in certain types of hazardous weather, such as heavy spring rains and heat waves" (HeW, 2012).

\section{Description of the study area}

Survey was carried out to study the impact of climate change on water resources and livelihood of Ladakh region. A case study of Chemday village panchayat was taken for the study, located in eastern part of Leh valley with geo-coordinate latitude $34.09 \mathrm{~N}$, longitude 74.79E; $3543 \mathrm{~m}$ altitude and adjoining villages are Egu, Gia, Kharu, Martsaylang, Sakti, Shara. The main objective behind identifying Chemday village is located in a valley which is supported by 3 sidedglacier streams and large number of water bodies in the form glacier streams, handpump, spring water on which people (household-300) survive in the lap of ChangLa glaciers. On the other hand, people mentioned the shortage of irrigation water for their annual but mono-cropping based subsistence agriculture they highly depend on Changla glaciers and Warila for irrigation purpose and also using hand pumps and spring water for drinking purpose. (http://wikiedit.org/India/Chemday/247202/).

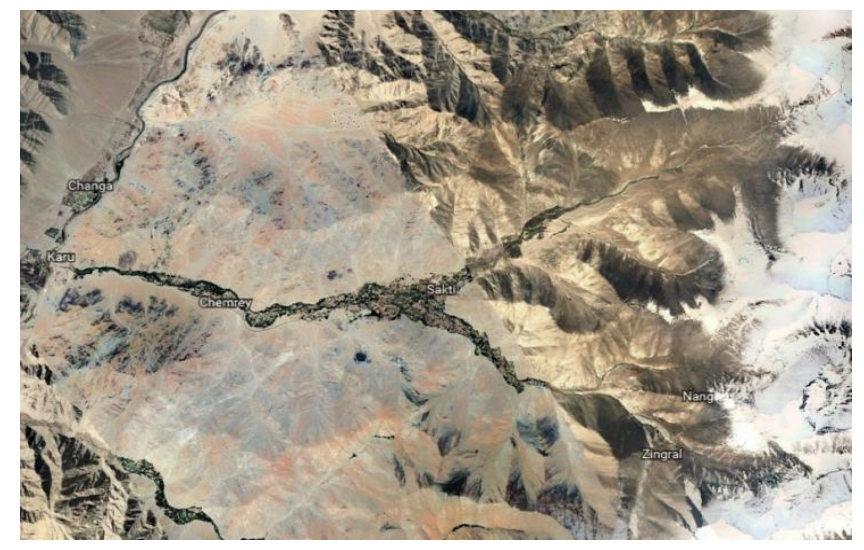

Major objectives of the study site is to explore the status of water availability and impact of climate change on water resources/ bodies in context to understand the present scenario of 
water availability and is a climate change affect on water resource of Chemday.

\section{Climate change and water resources in study area}

There is uncertainty surrounding the vulnerability of Ladakh to long-term climate change. Changes to temperature and winter snowfall are fundamental to water availability; this may increase melt water runoff, while decreasing water supply in the long term. Annual climatic changes are extreme (Le Masson 2013), with large temperature swings between summer and winter. Property is divided according to agricultural requirements. Villages have traditional and complex techniques for channeling irrigation; water is allocated by village and household, and if scarce, mediated by the chhu-pon (Lord of water), an elected village official. The high value and insecurity of water can make distribution, a much politicized issue (Angchok and Singh 2006).

The Trans-Himalayan region of India consists of Cold deserts of Ladakh and Himachal Pradesh. Valleys in these regions have highest permanent villages; receiving annual rainfall of only $100-140 \mathrm{~mm}$. A total of $97.5 \%$ of all the water on Earth is saltwater, leaving only the remaining $2.5 \%$ as freshwater and approximately $70 \%$ of the freshwater available on the planet is frozen in the icecaps of Antarctica and Greenland" (Govt. of Nepal (2011).

Also the paper highlights that, this leaves only the remaining $0.7 \%$ of the total water resources worldwide accessible for direct human uses. And this water is found in lakes, rivers, reservoirs and those underground sources that are shallow enough to be tapped at an affordable cost. This also is the only amount that is regularly renewed by rain and snowfall and therefore available on a sustainable basis.
Khan (2010) reported that, "Climate Change refers to the variation in the Earth's global climate or in regional climate over time". Rinchen Norbu Wangchuk (2018) revealed that the most critical impacts of climate change in Ladakh are related to increase in tourism and hydropower generation, stemming from glacier retreat, expansion of glacial lakes, and changes in seasonally and intensity of perception.

\section{Materials and Methods}

The main essence of this study is to explore the overall situation of water resources and its impact on the people that are using the resources and its water quality. For this study report we have conducted survey research to get the information regarding climate change and its impact on water resources. The research was conducted within the HMAARI SKUAST-K Leh. We conducted the survey research study in different area of Chemday, Sakti (chem.-sak) and Kharu. We did the survey research through purposive sampling. There were 10 respondents in the survey regarding the climate change and its impact on resources.

The methodological process is both qualitative and quantitative. In quantitative, survey questionnaire were prepared and filled up. But in qualitative case, interview and observation in three places were done. Some of data's are described and analyzed and some of them are transcribed and interpreted. The meanings are generated and analyzed in the narrative and descriptive forms.

\section{Results and Discussion}

The survey was conducted in the study area and different water resources management, peoples' contribution and water quality scenario with passing time etc. are presented in this section. 
Water resources management in cold arid regions

\section{Geo-Climatic Conditions}

Region of strategic defense importance

Snow bound rugged terrain with very meager natural vegetation

Remains landlocked during winters

Less oxygen availability with low humidity $(20-47 \%)$

Temperature ranges from $-35^{\circ} \mathrm{C}$ to $+35^{\circ} \mathrm{C}$

Precipitation as snow i.e. $9 \mathrm{~cm}(\mathrm{Leh}) \& 24 \mathrm{~cm}$ (Kargil)

Average wind speed: 70 nautical mile $/ \mathrm{hr}$

Short agricultural season (May-Sept)

Fragile ecosystem

\section{Sources of irrigation water}

In the hill region, the scope of boring tubewells, canals and even lift irrigation is limited, such facilities are confined to the low laying areas. Therefore, the most common source of irrigation remains the small water channels locally called Kuhls which intact accounts for 85.83 per cent of the total area under irrigation in hills

In cold deserts, some villages get water for irrigating their lands from some perennial torrents. In Spiti valley, the source of irrigation water is generally local nallas. Glacial water in cold deserts of Himachal Pradesh which forms the prime source of sustaining life in the region is brought to the field by making Kuhls (Water Channels).

In Kinnaur and other regions, the source of irrigation as well as drinking water is melting snow on the high peaks which runs downward in the shape of small and big nallahas (streams) and also spring out at certain points. In cold deserts, some villages get water for irrigating their lands from some perennial torrents. In Spiti valley, the source of irrigation water is generally local nallas. Glacial water in cold deserts of Himachal
Pradesh which forms the prime source of sustaining life in the region is brought to the field by making Kuhls (Water Channels).

In Kinnaur and other regions, the source of irrigation as well as drinking water is melting snow on the high peaks which runs downward in the shape of small and big nallahas (streams) and also spring out at certain points.

Utilization pattern of available water has tremendously changed if compared with past decades. Even local people have started consuming more water than what they used to do a decade ago. It is confirmed that weather is getting warmer, forcing people to increase their frequency of different utilization pattern in the light of temperature in Ladakh increased by $3^{\circ} \mathrm{C}$ between 1973 and 2008, while in the rest of India it increased by only $1^{\circ} \mathrm{C}$ as per Intergovernmental Panel on Climate Change. With the glacier on which Leh depends is likely to melt completely in the next five to six years, the demand for water is predicted to grow to 6 million litres by 2019 and volume of precipitation witnessing a southward trend, visitors to Ladakh has to act responsibly and reduce water usage.

Ground water varies due to large variation in topography. Depth of water is shallow in valley and deeper in the hilly areas of Ladakh region. Depth of water ranges from $1.3 \mathrm{~m}$ in Zorawar fort to $43.36 \mathrm{~m}$ below ground level in ITBP sites. Springs are the main source of water supply for domestic purposes and also serve for irrigation of crops. It marks the prominent seepage/ contact zone valley fill deposit with older formations and weak zone.

Constraints and strategies for sustainable livelihood

Low vegetation

Less oxygen concentration

Acute mountain sickness 
Sleep disturbances

Reduced physical efficiency

Prone to frostbite

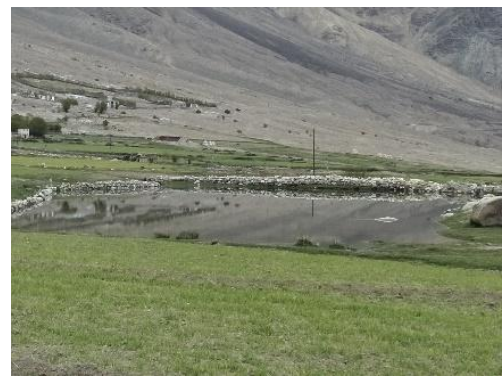

Chilling Zing

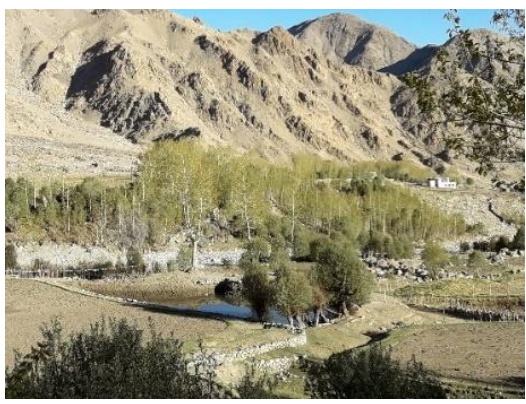

Stakmo zing
Reduced fresh food availability (Oct-April)

Fragile ecosystem

Remoteness and landlocked

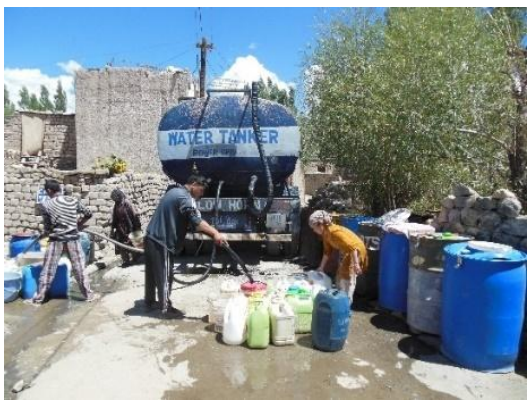

Facilities extended by LAHDC for drinking water and other uses where no facilities available in Leh city
High altitude remote regions like Ladakh have many constraints under cold arid region however simultaneously administration has developed strategies for enhancing runoff (Phuntsog et al., 2017). Constraints identified are low and erratic rainfall, highly permeable sandy terrain, high evaporative demand, deep and generally saline groundwater, target oriented development of water resources, poor socio-economic condition of local population, lack of education, reduced snowfall with $21 \%$ decrease glacierized area IHR (WWF, 2010) with glaciers less than 1 metre square retreating faster, higher dependency on natural resources, low receipt coincides with high demand pattern etc.

Possible strategies are techniques for enhancing runoff from catchments, traditional structure under practice in Ladakh is locally known as Zing which are small tanks, in which collects melted glacier water (Sharma and Mir, 2000), snow management is an important practice and source of irrigation water in cold arid regions but declining glacier recharge by 21 per cent has recently threatened few villages where sowing and irrigation has been seriously been affected.

\section{Artificial glacier}

Region is a dry land with difficult farming, and entire area depends on irrigation due to prevailing soil conditions and melting water from the glaciers through long, winding streams from upper mountain reaches. Melted water was the only source of irrigation for 80 percent of the villagers in Ladakh, where water is diverted to guiding channels and taken to a small tank-traditionally called ZING and distributed with the help of water manager Chhurpan. However, in recent times, decreased, scanty and untimely snowfall, retreating glaciers had an impact on domestic and agricultural needs.

This is all due to changing climate. Winters are getting shorter with more increasing number of rainy days but less precipitation under dry windy nature. The artificial glaciers have been innovated and located as far as possible closer to the village and at lower altitude so that it starts to melt much earlier as compared to a natural glacier i.e. in the month of April - May so as to supplement with additional irrigation water. During the winter months of November - December, the channel is built which divert/ guide the runoff 
water to the shady side of the mountain where it can slow down and freeze. On the other hand, due to short summer, mono-cropping is practiced from crucial month of April or May till September. Missing sowing at appropriate timing reduces yield by 50 per cent.

\section{Data analysis and interpretation}

The data collected from the survey is an interpreted and analyzed. There are both qualitative and quantitative data. Both the data sources are analyzed and interpreted as follows:

\section{Present Scenario of water availability in Chem-Sak}

According to the survey done in Chemday, Sakti, Kharu, almost $55 \%$ said that they have insufficient water. Remaining 45\% mentioned that they have sufficient water. The figure 1 shows that present scenario of water availability in Chem-sak is in sufficient.

\section{Sources of water}

The sources of water using by the people of Chem-Sak are analyzed and shown in Figure 2. In Chem-Sak village around 300 hand pumps were bored. As such no pipe lines exist in Chemday Sakti village. $70 \%$ people depend upon hand pump for drinking purpose. Almost $15 \%$ depend upon stream water. Remaining 5\% depend upon spring water for drinking water.

\section{Changes observed in water quality}

There are various sources of water that people of Chem-Sak are using. Water quality and sources of water are also changed with time. Quality of water has been analyzed and mention below in Figure 3.

It is observed from the figure that the quality of water is changing with passing time. As
$60 \%$ Chem-sak people mentioned that quality of water deceasing every year so rapidly and $35 \%$ peoples were not sure about changes.

\section{Reason behind the changes in water quality and quantity}

As per analysis of data collected through survey, it was observed that there has been change in quality as well as source of water also. Similarly the respondents said that there is declination in quality and quantity of water with time.

Regarding change in water quality, $80 \%$ people reported about increased tourism population and labors. Existence of toilet at Changla Top and Zingral (Warila) is in a very filthy and bad condition which is maintained by the army and local govt. There is a desperate need for a public convenience at Changla as it is the main water source for the people of Chem-sak, Kharu. The present condition is really pathetic and polluting the water source. Some10\% people said stream is far and not fit for drinking but the hand pump quality also decreased due to high Total Dissolve Solids. Remaining 10\% said that our spring got dried due to excessive discharge by army hence quantity and quality also decrease (Fig. 4).

\section{Reason behind water scarcity}

Chem-sak people mentioned that their village falls under water scarcity zone. Among the respondents $70 \%$ said water scarcity due to climate change and due to less snowfall as compare to time with 20-25 years back. Some $30 \%$ people said that it is due to improper management of water (Fig. 5).

\section{Change in water resources}

The figure 6 shows that major people has changed their water sources. It shows that the number of people who change the source of 
water is $65 \%$ and $30 \%$ still using same source of water and remaining $5 \%$ use both.

\section{Reason behind the change in water sources}

As per analysis and also through this chart, it is shown that $45 \%$ people changing water sources due to increase in water pollution in stream, 20\% due to long distance and 15\% people changed their source of water because they get water at home through hand pump. As such no pipe line were installed in this village. Remaining $20 \%$ is still using the same source of water (Fig. 7).

\section{Distance of Carrying Water}

The above figure 8 gives the distance of carrying water. Total of $65 \%$ peoples said that to fetch water its take around 15 minutes to cover the distance, $30 \%$ said that to fetch water its take around $1 / 2 \mathrm{hr}$ to $1 \mathrm{hr}$ to cover the distance and $5 \%$ people due to availability of hand pumps at home so only $0-5$ minutes distance to cover.

\section{Management of water resources}

The equal distribution of water resources for irrigation in this village is done by Churpon, head of water association. Churpon is the representative of whole village elected by the Chem-sak people. His responsibility is to make planning, execute the plan, and monitoring the plan to achieve equal distribution of water to each piece of agricultural land throughout whole season.

\section{Water for irrigation}

This part of information is about how the people irrigate their field. Whether the water is sufficient for irrigation or not? Also it helps to analyze the sources of water for irrigation and mentioned in Figure 9. Above given figure says that Maximum $85 \%$ people depend upon stream water for irrigation. In some season, people face the problem of insufficient irrigation water due to lack or less snowfall occurs in winter. $10 \%$ people depend upon hand pump during April-May for their nursery rising when proper ice melting is not happen. Remaining 5\% people who are near to spring also used that water for nursery rising and vegetable growing when initial irrigation is must.

\section{Sufficient water for irrigation}

Regarding the sufficient of water for irrigation, $80 \%$ chem.-sak people reported that the water is not sufficient for their crop. After 10-12 days interval they get irrigation for the crop. Few farmers, who grow cash crop, have to irrigate their field through hand pump because of insufficient water availability which affects the crop yield. $20 \%$ said that they don't face water crises because they are at upstream site (Fig. 10).

\section{Climate changing}

The trend of increasing climate change in the last 25 years in the Chem-Sak area is shown in Figure 11. We discussed with people of Chem-Sak about the climate change over the last 25 years. Most of the people i.e. 50\% said that they are feeling climate change, $30 \%$ said that climate change is increasing with increase in population and the demand. Remaining 20\% said that they didn't feel any change.

\section{Increase in dry periods}

Regarding our question about whether there is increase in dry period or not we come to know that almost $68 \%$ people said that they are facing the dry periods (Fig. 12).

Remaining 32\% said that they don't have any idea about the increase in dry period.

\section{Increase in climatic hazards}

About our queries regarding the increase in 
climatic hazards, it is found that $80 \%$ people were agree with increase in climatic hazards, $20 \%$ said that people crop hazard is increase due to climatic hazards. $0-1 \%$ said that they are not aware about these things.

\section{Types of climatic hazards}

Gathering information towards the different climatic hazards given in figure 13 which shows that maximum chemsak people said that flood/ cloud brust is the main climatic hazards that they are facing in last few years. Same time due to lack or less snow fall they face some year drought problem also due to water scarcity.

\section{Impact of climatic hazards on water}

As the study was undertaken to know the impact of climate change on water resources in context to climate hazards, $75 \%$ said that there is impact of climatic hazards on water resources, $35 \%$ said that climatic hazards are not the causes for bringing any change in water resources and $0-1 \%$ people have not any idea regarding this issue (Fig. 14).

Fig.1

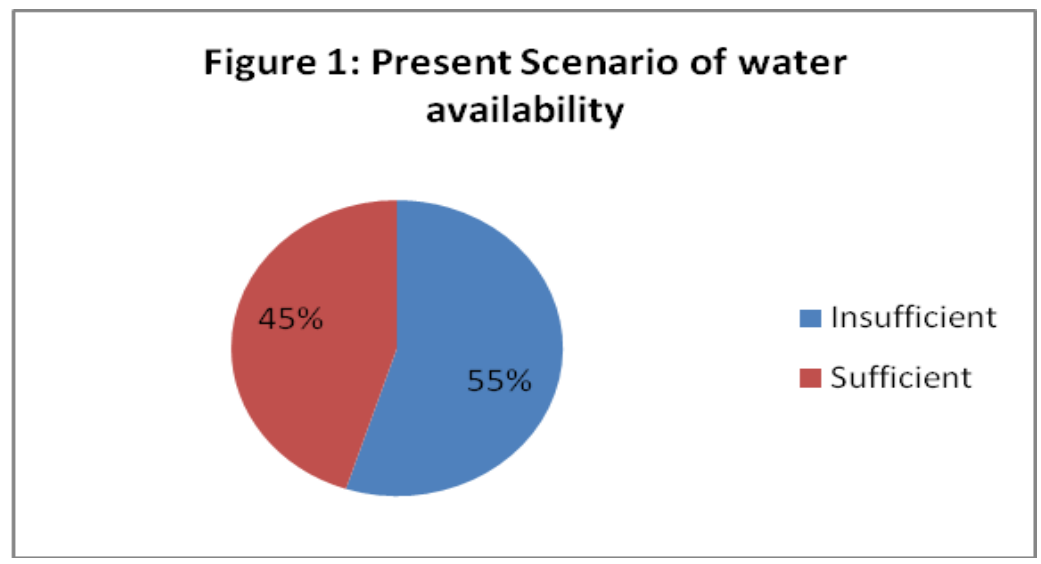

Fig.2

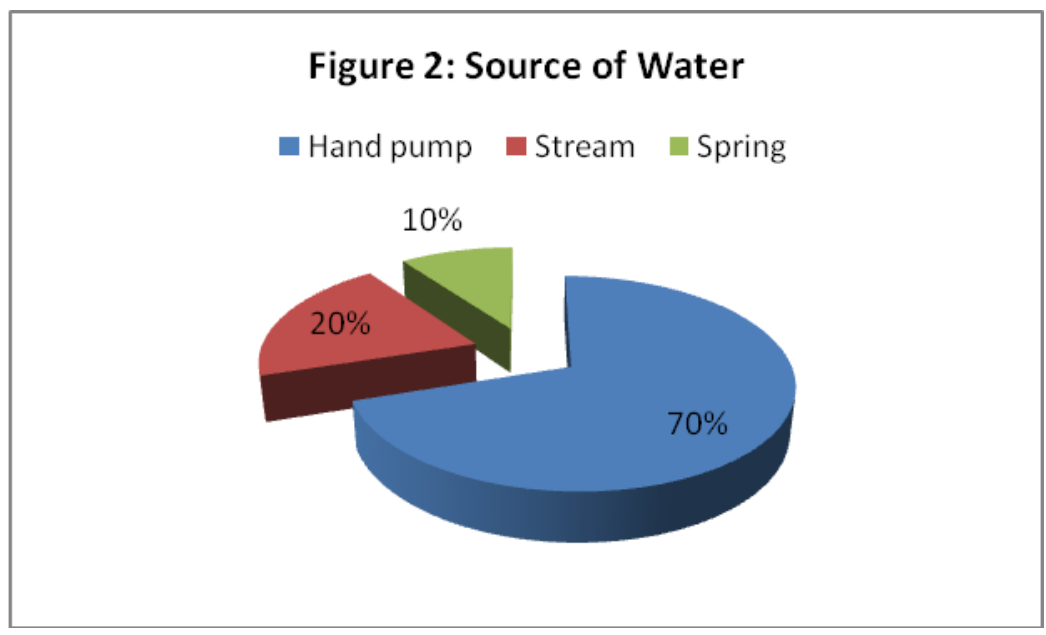


Fig.3

Figure 3. Peoples response for changing water quality with time

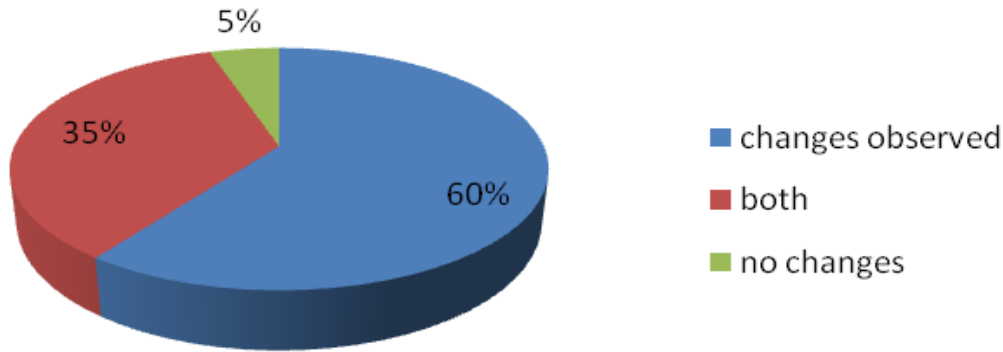

Fig.4

Figure 4: Reason behind the changes in water quality and quantity

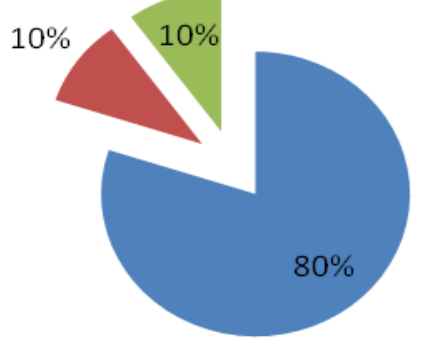

- Increasing tourism and labors

- High TDS of handpump

Washing \& Disposal garbage

Fig.5

Figure 5: Reason behind water scaracity

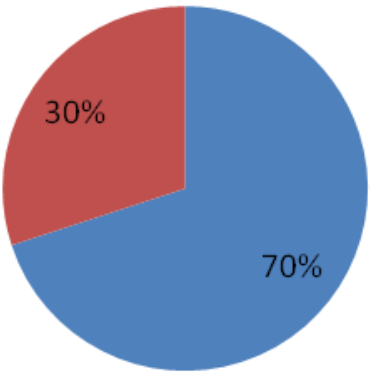

Climate change \& less snowfall

Not judically use 
Fig.6

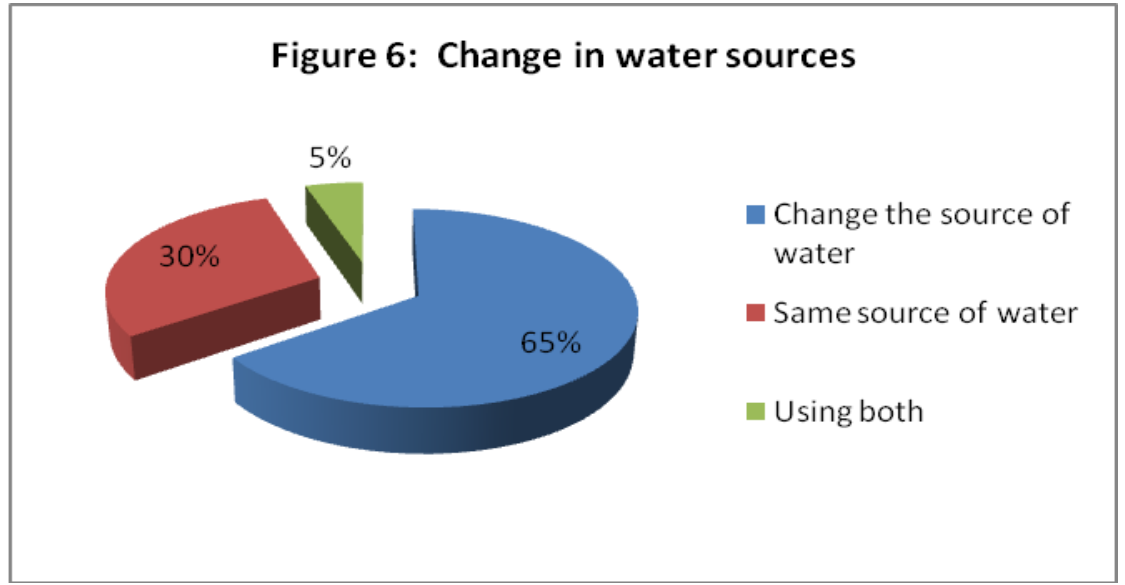

Fig.7

\section{Figure 7: Change in water sources}

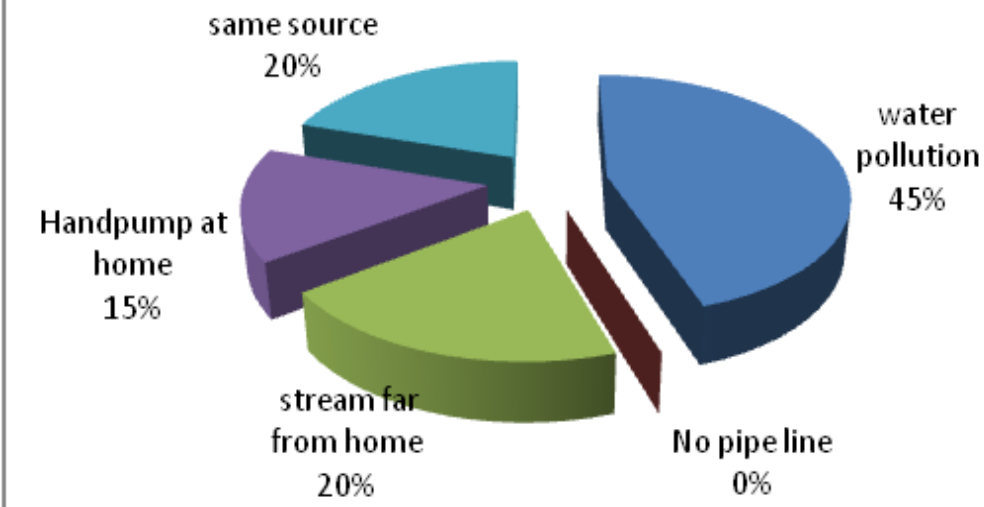

Fig.8

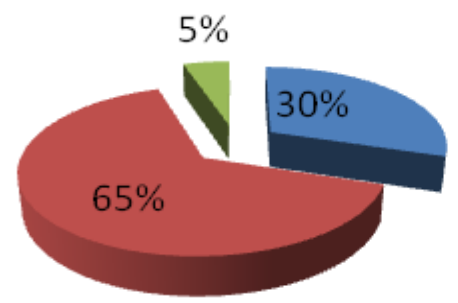

Time taken half hour

- Home service 0

- Time taken $15 \mathrm{mt}$

Figure 8: Distance for carrying water 
Fig.9

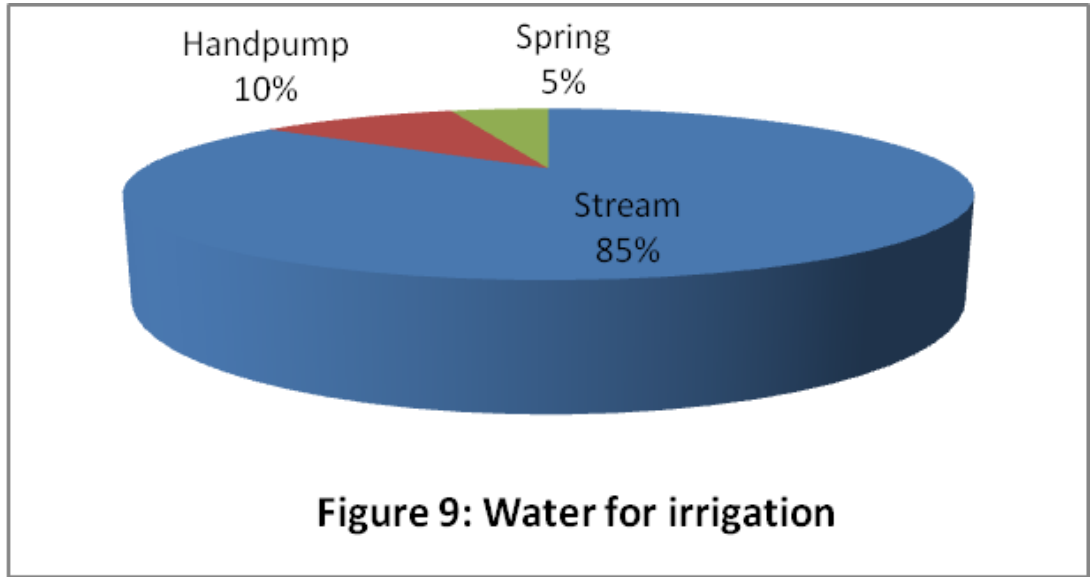

Fig.10

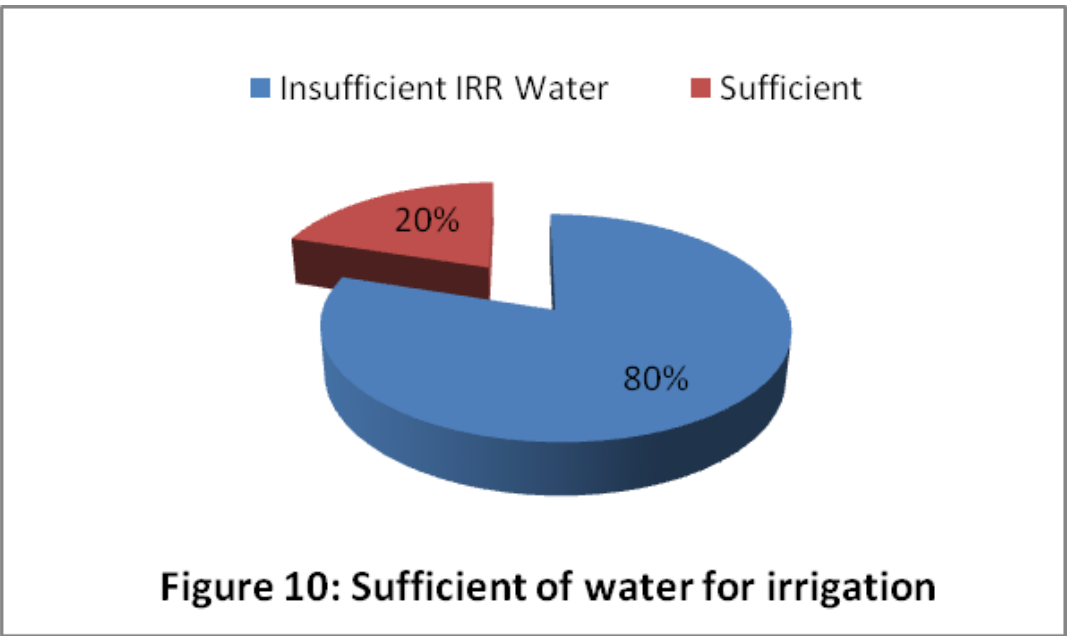

Fig.11

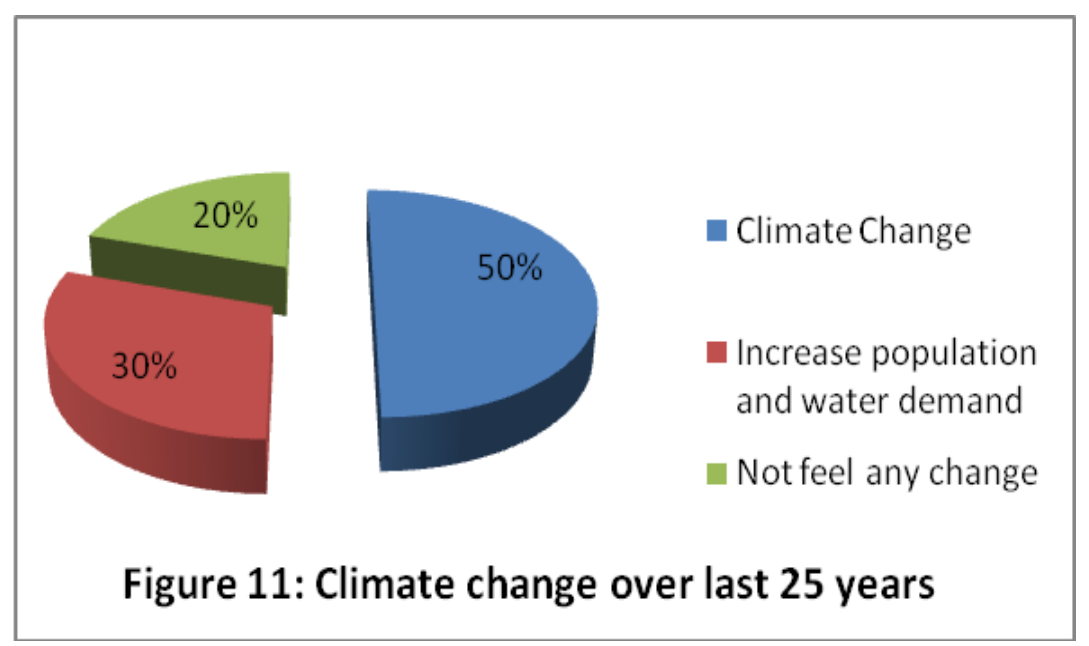


Fig.12

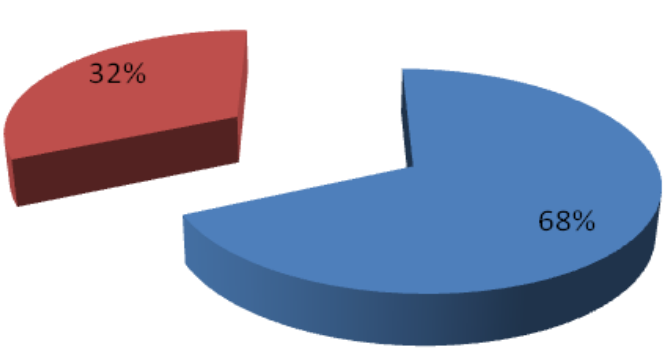

- Face Dry period

no idea

Figure 12: Increase in dry periods

Fig.13

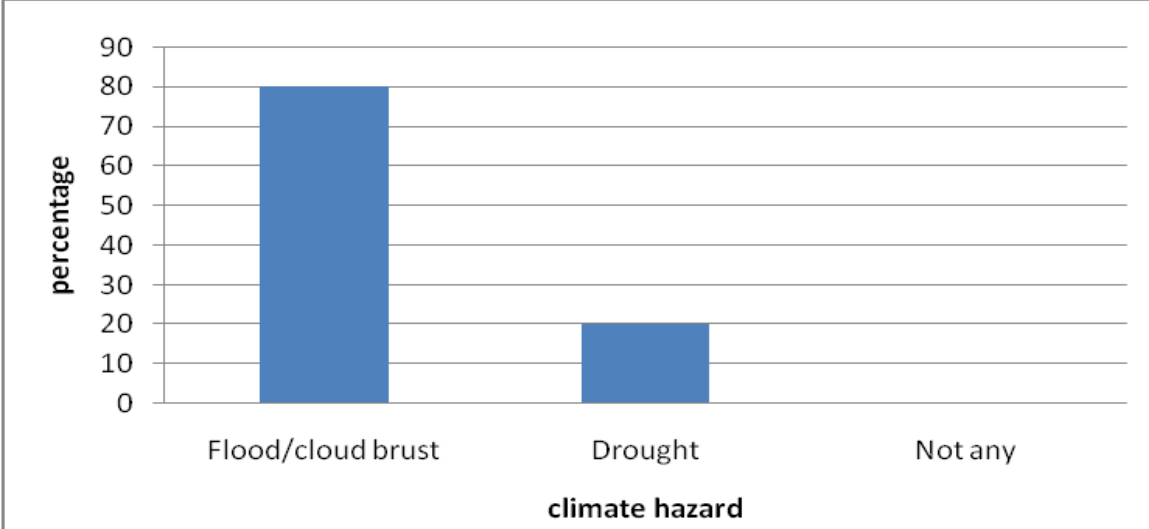

Figure 13: Increase in climate hazard

Fig.14

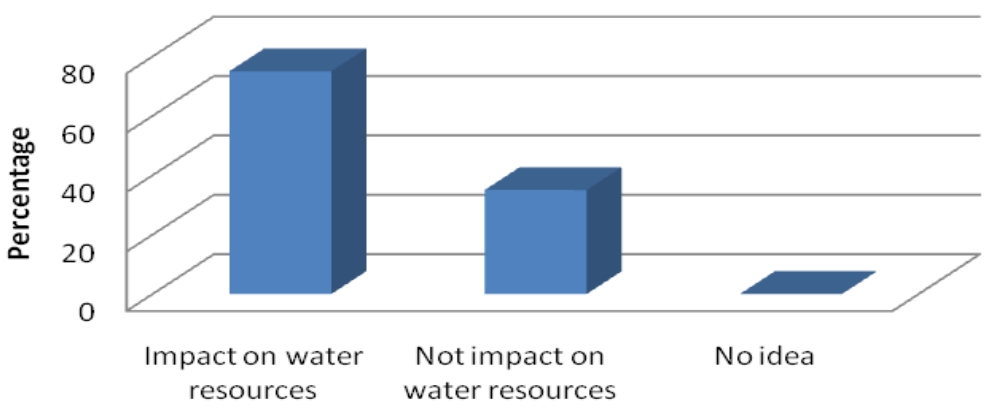

Figure 13: Impact of climatic hazards on water 


\section{Findings}

Climate change has been taken as a global problem. In the same way, the Chem-sak people also have told that climate change has great impact on water resources and other natural resources. If the timely information is not provided, there may be great consequences. Some of the major findings are given below.

The majority of $55 \%$ Chem-Sak people mention lack of water resources however $45 \%$ said sufficient water.

Mainly facing water scarcity during initial irrigation due to spring season as well as when less snowfall in winter.

Hand pumps, stream, springs are the main source of water. 300 handpumps are bore in Chem-Sak and $70 \%$ using this water sources. $20 \%$ still fetch water from stream. Remaining $10 \%$ depend on spring.

Quality of water is decreasing with time.

Majority of people $(80 \%)$ said that quality of water decrease due to increase in tourism population and labours at upstream site of mountain. $10 \%$ said decrease in water quality due to high TDS in handpump water.

$65 \%$ of people have been changing source of water.35\% still using same source of water. Remaining 5\% using both.

Maximum Distance covered to fetch the water take $1 / 2$ to $1 \mathrm{hr}$ when fetch water from stream.. Minimum time taken $0-5 \mathrm{mt}$ if hand pump was located near to home.

Churpon is the representative of all villagers. His responsibility to plan, executes, and monitors proper and equal distribution of water throughout the year.

Stream is main source of water for irrigation $85-90 \%$ people depend on steam water. $10 \%$ people use handpump water for nursery raising in springs. Remaining $10 \%$ used spring water for vegetable growing and nursery raising if it near to resident.

The majority of respondents (80\%) announced that Chem-Sak fall under water scaracity village.

Climate is getting warmer over last 25 years.20\% said have no idea of such condition.

Increased dry period is experienced by $68 \%$ of Chem-sak people. Remaining 32\% have no idea about such issue.

Chem-Sak faced climatic hazard (80\%)

Flood/cloud brust is the main climatic hazard, drought are other climatic hazard in the area.

The impact of hazard on water resources is more experienced.

The study about Chem-sak village in Ladakh region revealed that people have been facing effect of climate change such as decreased in source of water, long dry-windy season, possibility of flood and drought every year. This is just the initial sign for great disaster of future. Chem-Sak is a big village. Maximum tourist passes through this village to Pangong lake. With increase in frequency of tourism via this village including-Army camps at Warila enhancing the imbalance in natural resources. As already 300 numbers of handpumps exist till date and people exploiting ground water also. Meantime springs also get dried due to heavy extraction of groundwater by army. It's all because we are polluting our surface water that is stream water. If it is not stopped then in future it become very alarming situation for adjoining villages especially Chem-Sak to get access to utilizable portion of water.

It may be recommended that

Frequently cleaning of stream, mountain, spring, hand-pump areas from pollution.

Stop and make prohibit area for cloth washing 
Climate change awareness through campaign or their program should be conducted.

Strictly prohibit the hand-pumps sanction;

Proper measures should be taken to manage tourists keeping them away from sacred water resources.

Detailed investigation is required to explore saving the potential water resources;

Government agencies should pay attention to preserve Changla and Warila glaciers for conserve, Chemday, Sakti, Kharu, natural resources.

\section{References}

Agrawal, S., Raksakulthai, V., Aalst, M. N., Larsen, $\mathrm{P}$ and Smith, J (2003). Development and climate change in Nepal: Focus on water resources and hydropower pp. 16-42.

Angchok, D and Singh, S. (2006). Traditional irrigation and water distribution system in Ladakh. Indian Journal of Traditional Knowledge, 5(3) pp.397-402.

Dolma, K., Rishi, M.S and Lata, R. (2015). An appraisal of centralized waste water treatment plant with respect to Leh town. International Journal of Science and Research, 4(5), 754-759.

Government of Nepal (2011). Water Resources of Nepal in the context of climate change.

$\mathrm{He}$, W (2012). An Evaluation of prairie producer attitudes towards Climate Change. Unpublished Master's Thesis. University of Saskatchewa.

Kankia, N.A (2012). Environment and sustainable development. Journal of educational and social research 2:140143.

Karthikeyan and Hemalatha (2018) Kashmir: Melting glaciers threaten Ladakh's nature. https://www.aljazeera.com/indepth/featur es/kashmir-melting-glaciers-threatenladakh-nature-180513080600731.html

Khan, S.A (2010). Global warming and climate change. New Delhi: RVS Books.

Ladakh Autonomus Hill Development Council (LAHDC) 2005.Ladakh 2025 vision document, LAHDC, Leh Ladakh.

Norbu, R and Wangchuk (2018). Ladakh facing its worst water crisis ever: How its can effectively tackle climate change. https://www.thebetterindia.com/author/ri nchen-norbu-wangchuk.

Parajuli, R (2010). Climate Change and local impacts-synergy between adaptation and renewable energy development for Nepal 1-29.

Sharma, J.P and Mir, A.A. (2000). Dynamics of cold arid agriculture. Kalyani publisher, New Delhi, India

Tiwari, D.P and Nayak, H.C (2015). Climate change and its impact on global health. International Journal of Recent Research in Interdisciplinary Science. 2:29-38.

Tundup, P.,Wani, M.A., Dawa,S., Hussain, S and Laskit, J (2017). Water harvesting and conservation under cold desert condition of Ladakh $(\mathrm{J} \& \mathrm{~K})$ : constraints and strategies. Int.J.Curr. Microbiol.App.Sci. 6(2): 1796-1800. http://wikiedit.org/India/Chemday/247202/ https://www.geographyandyou.com/media/expe rt-column/ladakh-water-scenario/

\section{How to cite this article:}

Jigmet Yangchan, M.S. Raghuvanshi, Anil Kumar and Arya, C.K. 2019. Climate ChangeInduced Impact on Water Resource of Ladakh Cold Arid Region. Int.J.Curr.Microbiol.App.Sci. 8(05): 1996-2009. doi: https://doi.org/10.20546/ijcmas.2019.805.232 